\title{
SYNTESIS OF GROUP DECISIONS IN THE PROBLEM OF ANALYSIS OF THE TECHNICAL CONDITION OF MILITARY-CIVILIAN OBJECTS
}

Shved A. V. - PhD, Associate Professor of the Department of Software Engineering, Petro Mohyla Black Sea National University, Mykolayiv, Ukraine.

\section{ABSTRACT}

Context. Quite often, experts are involved in the process of diagnosis and monitoring the technical condition of buildings and structures, and in this case, situations might arise when expert data is generated under some specific types of uncertainty, and their possible combinations. This, in turn, necessitates the development of new approaches aimed at solving the problems of structuring and analytical processing of inaccurate, uncertain, fuzzy expert knowledge.

Objective. The methodology for choosing the category of technical condition of construction objects, including buildings and structures, and ranking the corresponding construction objects within the given category of the technical condition according to their degree of danger (expected damage in the event of an emergency) has been proposed in this paper. The proposed approach is based on the expert assessment methods and the mathematical apparatus of the evidence theory, which allows operating correctly with data generated under uncertainty, incompleteness, and inaccuracy. In order to improve the quality of combination results, it is proposed to use one of the proportional conflict redistribution rules and determine the optimal evidence combination order based on metrics in evidence theory.

Results. The paper proposes a methodology for the synthesis of group solutions for assessing the technical condition of civil, industrial and military-technical construction objects, and determining objects that primarily need maintenance or overhaul under complex forms of uncertainty and multi-alternatives. Application of the proposed methodology will allow rational distribution of available resources when planning preventive measures and carrying out repair work (overhaul, reconstruction, etc.) to increase the efficiency of their trouble-free operation.

Conclusions. The methodology proposed in this study constitutes the theoretical basis for the design of decision support systems for monitoring the technical condition of residential and/or non-residential real estate (buildings, structures) for various purposes.

KEYWORDS: evidence theory, technical condition category, ranking, expert judgments, uncertainty.

$T C$ - technical condition;

$B p a$ - basic probability assignment;

$D S T$ - Dempster-Shafer theory of evidence.

\section{NOMENCLATURE}

$\Omega_{j}^{(l)}$ is a vector that contains the numerical values of the degrees of expert's preferences formed by $j$-th expert for $l$-th category of technical condition;

$\alpha$ is an optimism coefficient;

$\mathrm{A}$ is a set of analyzed objects (alternatives);

$\mathrm{B}_{j}^{(i)}$ is a vector that contains the numerical values of the degrees of expert's preferences formed by $j$-th expert for $i$-th analyzed object;

$\mathrm{E}$ is a set of experts;

$\mathrm{H}$ is a set of profiles of expert preferences;

$\mathrm{K}$ is a set of categories of technical condition of building constructions;

$\mathrm{M}_{j}^{(i)}$ is a vector that contains the values of a basic probability assignment of corresponding subsets;

$O_{l}$ is a set of analyzed objects that correspond to (belong to) $l$-th category of technical condition;

$\mathrm{P}_{j}^{(l)}$ is a subset of preferences of the $j$-th expert regarding the analyzed objects that correspond to (belong to) $l$-th category of technical condition;

$\mathrm{RA}^{(i)}$ is a ranking of categories of technical condition for $i$-th analyzed object;

$R K_{l}$ is a ranking of analyzed objects that belong for $l$ th technical condition category;
$\mathrm{R}_{r e z}$ is a final ranking, with elements corresponding to collective rankings of the analyzed objects for each category of TC.

$X_{j}^{(i)}$ is a subset of preferences of the $j$-th expert regarding the analyzed objects that correspond to (belong to) $i$-th analyzed object;

$d$ is a total number of selected subsets (groups of elements) by $j$-th expert for $i$-th analyzed object;

$m()$ is a basic probability assignment of corresponding subset;

$m_{d+1}()$ is a basic probability assignment of frame of discernment;

$m_{12}()$ is a combined basic probability assignments of $m_{1}()$ and $m_{2}()$;

$w_{j}$ is a weight coefficient (competency coefficient) of the $j$-th expert;

$2^{\Omega}$ is a power-set of all possible subsets of $\Omega$, including the empty set;

$|\cdot|$ is a cardinality of the corresponding subset;

$\oplus$ is a evidence combination rule.

\section{INTRODUCTION}

In recent decades, a steady trend of physical and moral aging of fixed assets, which include buildings and structures, has been established in Ukraine Buildings are subject to a variety of influences, they wear out, age, collapse, causing their performance to deteriorate, and over time they cease to be fit for purpose.

For example, experts estimate that about $60 \%$ of the country's housing stock needs major overhaul, and the overall level of communal infrastructure deterioration exceeds $60 \%$. 
In this regard, the task of monitoring and evaluation of the TC of buildings and structures acquires particular importance to ensure safe operation and operational reliability of building constructions and structures. Regular monitoring of the TC of building structures is aimed at the timely adoption of measures to prevent and eliminate emerging negative processes in order to increase the efficiency of accident-free continuous operation of facilities; to develop forecasts of changes in the TC of buildings and structures, in order to study the dynamics of deformation processes.

Nowadays, in Ukraine, a comprehensive methodology for evaluation and monitoring of the TC of structures, buildings have not been approved, which would be unambiguous, formalized, and experimentally confirmed. Experts (specialists) in the field of structures of buildings and constructions defects diagnosis note the absence of clear recommendations for making justified decisions on the TC of structures and buildings in general, fixed in the current regulatory documents.

There is a lack of communication between the regulatory documents; insufficient evaluation criteria formulated, few and limited signs of classification of the structures and the buildings to a particular category of TC. Signs of the categories of TC of building constructions and structures are not sufficiently developed both theoretically and practically.

The object of study is the group expert evaluations of TC categories of building constructions and structures, that require structuring and aggregation in order to synthesize collective management decisions (building demolition, reinforcement, repair, reconstruction, etc.).

The subject of study is the models and methods of analysis and structuring of group expert evaluations of TC categories of building constructions and structures, based on the mathematical apparatus of evidence theory.

The purpose of the work is to develop a methodology for determining the category of the TC of building constructions and structures, and selection of considered construction objects for their renovation, restoration, overhaul, etc. under group decision-making process.

\section{PROBLEM STATEMENT}

Let us consider a set of analyzed objects (alternatives) $\mathrm{A}=\left\{A_{i} \mid i=\overline{1, n}\right\}$, a set of categories of TC of building constructions $\mathrm{K}=\left\{K_{l} \mid l=\overline{1, s}\right\}$ and a set of experts $\mathrm{E}=\left\{E_{j} \mid j=\overline{1, t}\right\}$.

It is necessary to determine a TC category for each given alternative: $\forall A_{i} \in \mathrm{A}, i=\overline{1, n}:\left(A_{i}, K_{l}\right), \quad l=\overline{1, s}$. The pair $\left(A_{i}, K_{l}\right)$ defines the belonging of the object $A_{i}$ to the category $K_{l}$. And make collective expert ranking of $A_{i}^{(l)}$ for selected TC category $K_{l}$, which allows to choose from a set $\mathrm{A}$ one alternative $A_{i}^{(l)}$ (or a few equivalent $\left.A_{i}^{(l)} \sim A_{p}^{(l)}\right)$ that are most in need of overhaul, restoration (C) Shved A. V., 2019 DOI 10.15588/1607-3274-2019-4-9

$$
\begin{gathered}
\text { etc.: } \quad R K_{l}:\left\{A_{1}^{(l)} \succ A_{2}^{(l)} \succ \ldots \succ A_{i}^{(l)} \succ \ldots \succ A_{z}^{()}\right\} \\
R K_{l}:\left\{A_{1}^{(l)} \succ A_{2}^{(l)} \succ \ldots \succ A_{i}^{(l)} \sim A_{p}^{(l)} \succ \ldots \succ A_{z}^{l)}\right\} .
\end{gathered}
$$

\section{REVIEW OF THE LITERATURE}

A significant number of publications are devoted to various aspects of assessment of the buildings TC. So, [15] are offered the issues of reliability, physical and moral deterioration of building structures and constructions, and a number of methods of determination of TC of building structures based on results of a building technical inspection are considered. For example, [1] is studied various test methods for building diagnosis and condition assessment. The comparative analysis of building condition assessment methods widely used in European countries is carried out in [2]. The authors of the [3] proposed a method for calculating condition index of corrosion distressed reinforced concrete buildings based on mathematical apparatus of fuzzy logic. Obtained index allows evaluating condition and repair needs of the buildings and structures.

It can bee allocate a number of works using methods of expert estimation in a problem of diagnosis of TC of buildings and structures [6-10]. The authors of [6,7] have presented a fuzzy-based assessment model, that allows to carry out diagnostics of building structures under uncertainty and ambiguity. In particular, the authors of the [6] used the proposed technique for evaluating of importance of structural assessment criteria for reinforced concrete structures, and at the same time as the authors of the [7] have calculated corrosion damage of bridge superstructures. [8] proposes the methodology for bridge condition evaluation (for maintenance actions and budget allocation) using the Analytic Hierarchy Process (AHP) method. The authors of the [9] have proposed the expert assessment of model that calculates the degree of deterioration of engineering assets with a long service-life under uncertainty. The method of expert assessment in the diagnosis of the TC of buildings under a limited number of statistical data from instrumental inspection and inaccuracy of information based on the fuzzy decisionmaking methods has been proposed in [10].

At the same time, it is worth mentioning the papers that are aimed at automating the process of assessment of the TC of operated buildings constructions. These works are devoted to the development and use of intelligent systems for diagnosing the TC of building constructions and structures [11-14]. These systems use the accumulated experience and knowledge of experts and current information about the state of the building structure: [11] proposes condition assessment system for sustainable constructions that uses five-point colourcoded condition assessment rating for performance evaluation criteria, such as risk; a prototype computing system for safety diagnosis of middle and small-size buildings have been proposed in [12]; the concept of expert system of diagnostics of technical condition of buildings and constructions is given in [13]; [14] suggests 
the concepts of expert information system for building diagnosis based on integrative use of expert system technology and remote monitoring technology.

An analysis of numerous publications in the field of diagnostics of TC showed that the process of assessing and monitoring the TC of building structures is carried out by combining agreed and complementary research calculation and analytical procedures, the list and completeness of which in each case is specified by the specialized organization conducting the survey. And an essential place in this process is occupied by expert assessment methods. It is imperative to select methods of analysis and processing of expert data carefully and take into account various forms of ignorance, such as incompleteness, fuzziness, and uncertainty.

At the same time, quite often in practice, there are situations characterized simultaneously by various forms of ignorance, for example, a combination of uncertainty and inaccuracy. The mathematical theory of evidence (Dempster-Shafer Theory) is a useful mathematical tool for modeling and analyzing some specific types of uncertainty [15-17].

\section{MATERIALS AND METHODS}

The TC is defined by a set of properties of a building (structure) or its elements (constructions), which is characterized at a certain point of time by the signs established by the regulatory and technical documentation for this building (structure) or its elements, and reflecting the level of operational suitability. The TC of the building (structure) is a combination of qualitative and quantitative indicators, which characterize the serviceability of the building and its parts in comparison with their maximum permissible values.

Assessment of the TC building constructions and structures includes determining the category of the TC of building structures taking into account the degree of damage and the magnitude of the reduction in bearing capacity; establishing the operational suitability of building structures according to basic criteria or the need for their overhaul (restoration, reconstruction, etc.). The criteria of TC assessing depend on the functional purpose and design of buildings and structures, the type of building structures, the material used, and other factors.

The paper proposes a methodology for determining the category of TC of building structures, and selecting the considered building objects (buildings, structures) for overhaul, within the framework of a given category of $\mathrm{TC}$, or for all categories of TC. Let us consider the stages of the proposed methodology.

1 Determining technical condition category of building structures

First, it is necessary to survey building constructions and structures by visual inspection, instrumental measurements, and tests in natural and laboratory conditions. As a result of this procedure, a set of quantitative and qualitative indicators of the serviceability of the building (structure), its parts and structures will be formed. Further, an expert group, which includes experts, (c) Shved A. V., 2019 DOI 10.15588/1607-3274-2019-4-9 representatives of building repair and construction organizations, etc., determines the category of TC of building constructions and structures for each object under consideration in accordance with the set of quantitative and qualitative characteristics of their operational condition.

Let us consider a set of analyzed building objects (alternatives) $\mathrm{A}=\left\{A_{i} \mid i=\overline{1, n}\right\}$, a set of categories of TC of building constructions $\mathrm{K}=\left\{K_{l} \mid l=\overline{1, s}\right\}$ and a group of experts $\mathrm{E}=\left\{E_{j} \mid j=\overline{1, t}\right\}$, who form the profiles of expert preferences $\mathrm{H}=\left\{\gamma_{j} \mid j=\overline{1, t}\right\}$. It is necessary to determine a TC category for each given alternative: $\forall A_{i} \in \mathrm{A}$, $i=\overline{1, n}: \quad\left(A_{i}, K_{l}\right), \quad l=\overline{1, s}$. The pair $\left(A_{i}, K_{l}\right)$ defines the belonging of the object $A_{i}$ to the category $K_{l}$.

The procedure of determining the TC category based on the mathematical apparatus of the theory of evidence consists of the following sequential iterations:

1.1 Expert preferences identification

Each expert $E_{j} \in \mathrm{E}$ is invited to determine a $\mathrm{TC}$ category $K_{l} \in \mathrm{K}$, or to distinguish some groups of TC categories $Y_{k}=\left\{K_{l} \mid l=\overline{1, s}\right\}, 1 \leq s \leq z, Y_{k} \subseteq \mathrm{K}$, and to set the corresponding numeric value $b_{k}$ within the given scale of expert measurements, which describes the degree of preference of the analyzed object in relation to the set of other options (to a set K), for all analyzed objects $A_{i} \in \mathrm{A}$.

An expert can establish several categories at once, for the analyzed object, or even refuse to evaluate them if he is not sure about his choice. As a result of the corresponding procedure, a set $\mathrm{H}=\left\{\gamma_{j} \mid j=\overline{1, t}\right\}$ will be formed, each element of which represents the expert preferences profiles of the categories of TC of the analyzed objects $\gamma_{j}=<X_{j}^{(i)}, B_{j}^{(i)}>, i=\overline{1, n}$. Each subset $X_{j}^{(i)}=\left\{Y_{k} \mid k=\overline{1, d}\right\}, \quad d \leq 2^{|\mathrm{K}|}$ reflects the preferences (choice) of the expert $E_{j} \in \mathrm{E}$ regarding the category (s) of the TC of the object $A_{i} \in \mathrm{A}$. Any subset of $Y_{k}$ contains the preferred categories (groups of categories) of the TC $K_{l} \in \mathrm{K}$ of the analyzed object $A_{i} \in \mathrm{A}$ and can be built on the basis of the next rules [15-17]:

1. $Y_{k}=\{\varnothing\}$;

2. $Y_{k}=\left\{K_{l}\right\}$;

3. $Y_{k}=\left\{K_{l} \mid l=\overline{1, g}\right\}, g<s$;

4. $Y_{k}=\mathrm{K}=\left\{K_{l} \mid l=\overline{1, s}\right\}$.

Thus, for each alternative $A_{i} \in \mathrm{A}$, a subset system $\left\{X_{j}^{(i)} \mid j=\overline{1, t}\right\}$ will be formed that displays the choice of all experts regarding the TC category of $A_{i} \in \mathrm{A}$. 
For each subset system $X_{j}^{(i)}=\left\{Y_{k} \mid k=\overline{1, d}\right\}$ a vector $\mathrm{B}_{j}^{(i)}=\left\{b_{k} \mid k=\overline{1, d}\right\}$ will be formed, which contains the numerical values of the degrees of preference $b_{k}$ of $Y_{k} \subseteq X_{j}^{(i)} \quad\left(Y_{k} \succeq \mathrm{K}\right)$, selected by the expert $E_{j}$ for each analyzed object $A_{i} \in \mathrm{A}$.

If the expert $E_{j}$ refused to evaluate $A_{i}$, then we accept that his choice is equal to $X_{j}^{(i)}=\varnothing$, which reflects a situation of complete ignorance of the expert regarding the current choice.

1.2 Determining basic probability assignment of corresponding subsets $Y_{k} \subseteq X_{j}^{(i)}$

For each formed subset system $X_{j}^{(i)}=\left\{Y_{k} \mid k=\overline{1, d}\right\}$, a vector $\mathrm{M}_{j}^{(i)}=\left\{m_{k} \mid k=\overline{1, d+1}\right\}$ will be obtained, the elements of which are calculated by the next formulas [17]:

$$
\begin{gathered}
m_{k}\left(Y_{k}\right)=\frac{b_{k} \cdot w_{j}}{\sum_{i=1}^{d} b_{k} \cdot w_{j}+\sqrt{d}},(i=\overline{1, d}) ; \\
m_{d+1}(\mathrm{~K})=\frac{\sqrt{d}}{\sum_{i=1}^{d} b_{k} \cdot w_{j}+\sqrt{d}} .
\end{gathered}
$$

The value $m_{d+1}(\mathrm{~K})$ reflects the degree of complete ignorance of $E_{j}$ corresponding to the object $A_{i} \in \mathrm{A}$.

1.3 Determination of the order of experts' evidence combination

Determination of the order of evidence combination based on dissimilarity measures in evidence theory allows getting more effective results of combination.

To perform this procedure, the degree of difference between $X_{j 1}^{(i)}$ and $X_{j 2}^{(i)}, \forall\left(j_{1}, j_{2}\right)=\overline{1, t}$, is calculated based on e.g. the measure [18]:

$$
d_{J}\left(\mathrm{M}_{j 1}^{(i)}, \mathrm{M}_{j 2}^{(i)}\right)=\sqrt{\frac{1}{2}\left(\mathrm{M}_{j 1}^{(i)}-\mathrm{M}_{j 2}^{(i)}\right)^{T} D\left(\mathrm{M}_{j 1}^{(i)}-\mathrm{M}_{j 2}^{(i)}\right)} .
$$

Elements of the $2^{|\mathrm{K}|} \times 2^{|\mathrm{K}|}$ matrix $D=\left\{d_{s p}\right\}$, $d_{s p}=\left|Z_{s} \cap Z_{p}\right| /\left|Z_{s} \cup Z_{p}\right|$ measure the difference between elements (subsets) $Z_{s}$ and $Z_{p}$ of the set $2^{\mathrm{K}}$.

The value of $d_{J}\left(\mathrm{M}_{j 1}^{(i)}, \mathrm{M}_{j 2}^{(i)}\right) \in[0,1]$ represents the distance, which reflects the difference and expresses the degree of conflict between $\mathrm{M}_{j 1}^{(i)}$ and $\mathrm{M}_{j 2}^{(i)}$.

For aggregation the corresponding values of $\mathrm{M}_{j 1}^{(i)}, \ldots$, $\mathrm{M}_{j t}^{(i)}$, at each stage of combination such $\mathrm{M}_{j 1}^{(i)}$ and $\mathrm{M}_{j 2}^{(i)}$ are selected which satisfy the below condition: $\min \left(d_{\mathcal{J}}\left(\mathrm{M}_{j 1}^{(i)}, \mathrm{M}_{j 2}^{(i)}\right)\right), \forall\left(j_{1}, j_{2}\right)=\overline{1, t}$.

(C) Shved A. V., 2019

DOI 10.15588/1607-3274-2019-4-9
1.4 Aggregation of expert evidence

Aggregation of expert evidence in the notation of the mathematical theory of evidence is carried out by combining the obtained basic probability assignments $\mathrm{M}_{j}^{(i)}=\left\{m_{k} \mid k=\overline{1, d+1}\right\}$ for all experts $E_{j}, \quad(j=\overline{1, t})$. Thus, $t-1$ combining operations will be performed.

To obtain aggregated estimates, it is recommended to use one of the proportional conflict redistribution rules. Since when using any of these rules, the resulting combined basic probability assignments are formed by adding parts of the total conflict mass or local conflict masses to the corresponding value $m(\cdot)$. In this case, the resulting subsets correspond to the original ones; new subsets are not formed.

The combined basic probability assignments $m_{P C R S}(C)$ according to the proportional conflict redistribution rule PCR5 $\left(\forall C \subset 2^{\mathrm{K}} \backslash\{\varnothing\}\right)$ are calculated based on the expression [19]:

$$
\begin{aligned}
& m_{P C R 5}(C)=m_{12}(C)+ \\
& +\sum_{\substack{Y \in 2^{\mathrm{K}} \backslash\{X\} \\
X \cap Y=\varnothing}}\left[\frac{m_{1}(X)^{2} \cdot m_{2}(Y)}{m_{1}(X)+m_{2}(Y)}+\frac{m_{2}(X)^{2} \cdot m_{1}(Y)}{m_{2}(X)+m_{1}(Y)}\right] .
\end{aligned}
$$

In equation (5), $m_{12}(C)$ corresponds to the combined basic probability assignments for the subset $C=X \cap Y$, which is calculated based on conjunctive consensus.

As a result of combination produce the set $X_{\text {rez }}^{(i)}=\left\{Y_{r k}^{(i)} \mid r k=\overline{1, q}\right\}, q \leq 2^{|\mathrm{K}|}-1 \quad$ (except the empty set), will be obtained. This set contains the resulting subsets obtained by combining $X_{j 1}^{(i)}$ and $X_{j 2}^{(i)}$, $\forall\left(j_{1}, j_{2}\right)=\overline{1, t}$, and a vector $\mathrm{M}_{\mathrm{rez}}^{(i)}$ containing the basic probability assignments $m_{\text {rez }}\left(Y_{r k}^{(i)}\right)$ of the resulting subsets $Y_{r k}^{(i)}$ for the $A_{i} \in \mathrm{A}$.

1.5 Construction of the final ranking of categories of TC for $A_{i}$

For final ranking construction, it is necessary to calculate the values of belief $\operatorname{Bel}(X)$ and plausibility $P l(X)$ function, which in the mathematical theory of evidence represent the upper and lower bounds of the interval that contains the exact probability value $P(X)$ of subset $X$.

The $\operatorname{Bel}(\cdot)$ and $P l(\cdot)$ function are calculated for each subset $Y_{r k}^{(i)}$ in the following way:

$$
\begin{aligned}
& \operatorname{Bel}(X)=\sum_{Y \subseteq X} m(Y) ; \\
& P l(X)=\sum_{Y \cap X \neq \varnothing} m(Y) .
\end{aligned}
$$

The priority of the subset $Y_{r k}^{(i)}$ is established by comparing the obtained intervals $\left[\operatorname{Bel}\left(\left\{Y_{r k}^{(i)}\right\}\right), \operatorname{Pl}\left(\left\{Y_{r k}^{(i)}\right\}\right)\right]$ formed by belief and plausibility function. 
The element (a subgroup of elements of the original set) is considered as the best choice if belief and plausibility function values for it are the largest among similar values of all elements.

In the case when the considered intervals are nested, their comparison can be carried out using the expression:

$$
\alpha \cdot \operatorname{Bel}\left(\left\{Y_{r k}^{(i)}\right\}\right)+(1-\alpha) \cdot P l\left(\left\{Y_{r k}^{(i)}\right\}\right), \alpha \in[0,1] .
$$

The result of mathematical model construction is a final ranking of categories of $\mathrm{TC}$ for each given alternative $A_{i}, \quad i=\overline{1, n}$, that displays the choice of all experts:

$$
\mathrm{RA}^{(i)}:\left\{K_{1}^{(i)} \succ K_{2}^{(i)} \succ \ldots \succ K_{i}^{(i)} \succ \ldots \succ K_{l}^{(i)}\right\} .
$$

1.6 Determination of category of TC for $A_{i}$

Next, for each $A_{i}$, a category of TC is selected that meets the below condition: $\max \left(m_{\text {comb }}\left(K_{l}\right)\right)$. Thus, for each category of TC $K_{l}$, a set of objects can be obtained that corresponds to it: $O_{l}=\left\{A_{i}^{(l)} \mid i=\overline{1, z}\right\}, z \leq n$.

At the next stage, the expert group performs the ranking of objects (building constructions and structures) within a given category of TC following the data obtained at the previous stage regarding the belonging of the analyzed object to a particular category of TC.

2 Ranking objects within a given category of technical condition

The task is to obtain the resulting ranking of considered objects (buildings, structures, etc.) according to the potential damage and the significance of the object, which makes it possible to rationally allocate available resources during the planning of the preventive measures and overhaul, increase the operational reliability and stability of building constructions for military-civilian use.

Let us consider a set of analyzed objects (alternatives) $\mathrm{A}=\left\{A_{i} \mid i=\overline{1, n}\right\}$, a set of categories of $\mathrm{TC}$ of building constructions $\mathrm{K}=\left\{K_{l} \mid l=\overline{1, s}\right\}$ and a set of experts $\mathrm{E}=\left\{E_{j} \mid j=\overline{1, t}\right\}$. At the previous stage, for each category of TC $K_{l}$, a set of objects was obtained that corresponds to $K_{l}: O_{l}=\left\{A_{i}^{(l)} \mid i=\overline{1, z}\right\}, z \leq n$. It is necessary to make a ranking of corresponding building constructions $A_{i}^{(l)}$ within the given category $K_{l}$ by a degree of their damage (expected damage in the event of an emergency) and the need of an overhaul:

$$
\begin{gathered}
R K_{l}:\left\{A_{1}^{(l)} \succ A_{2}^{(l)} \succ \ldots \succ A_{i}^{(l)} \succ \ldots \succ A_{z}^{l)}\right\}, \text { or } \\
R K_{l}:\left\{A_{1}^{(l)} \succ A_{2}^{(l)} \succ \ldots \succ A_{i}^{(l)} \sim A_{p}^{(l)} \succ \ldots \succ A_{z}^{l)}\right\} ; \\
\mathrm{R}_{r e z}=\left\{R K_{l} \mid l=\overline{1, s}\right\} .
\end{gathered}
$$

The procedure for constructing a ranking model for building objects based on the mathematical apparatus of evidence theory consists of the following steps:
2.1 Expert preferences identification

The expert $E_{j} \in \mathrm{E}$ forms a system of subsets $\mathrm{P}_{j}^{(l)}=\left\{P_{i}^{(l)} \mid i=\overline{1, f}\right\}, \quad f \leq 2^{\left|O_{l}\right|}, \quad P_{i}^{(l)} \subseteq O_{l}$, reflecting their preferences (choice) regarding the degree of technical wear of buildings and repair work required for object $P_{i}^{(l)}$ (provided that $\left|P_{i}^{(l)}\right|=1$ ), or group of objects (if $\left|P_{i}^{(l)}\right|>1$ ), corresponding to the $K_{l}$ in accordance with (1). Next, $E_{j} \in \mathrm{E}$ sets numerical values $\omega_{i}^{(l)}$ that reflects the degrees of preference $P_{i}^{(l)}$ relative to $O_{l}$ in values of a given scale of expert preferences, $\Omega_{j}^{(l)}=\left\{\omega_{i}^{(l)} \mid i=\overline{1, f}\right\}$.

2.2 Determining basic probability assignments of corresponding subsets $P_{i}^{(l)} \subseteq O_{l}$

Then, for each formed subset system $\mathrm{P}_{j}^{(l)}=\left\{P_{i}^{(l)} \mid i=\overline{1, f}\right\}$, a vector $\mathrm{M}_{j}^{(l)}=\left\{m_{k} \mid k=\overline{1, f+1}\right\}$, that contains the values of a basic probability assignment of subset $P_{i}^{(l)}$, will be obtained. The elements of $\mathrm{M}_{j}^{(l)}$ can be calculated using the procedure described in Section 1.2 .

2.3 Aggregation of expert evidence

Aggregation of individual expert assessments is carried out on the basis of the operation of the combination of received expert evidence $\mathrm{P}_{j}^{(l)}=\left\{P_{i}^{(l)} \mid i=\overline{1, f}\right\}$ and the corresponding values of $\mathrm{M}_{j}^{(l)}=\left\{m_{k} \mid k=\overline{1, f+1}\right\}$ for a given category $K_{l}$ according to the estimates of all experts.

The order of experts' evidence combination is determined in accordance with the procedure given in Stage 1.3. It is recommended to use the rule (5) as a combination rule.

As a result of combination procedure, in accordance with the selected combination rule, the set $\mathrm{P}_{\text {rez }}^{(l)}=\left\{P_{r i}^{(l)} \mid r i=\overline{1, v}\right\}, \quad v \leq 2^{\left|O_{l}\right|}-1$, will be obtained, containing the resulting subsets obtained by combining $\mathrm{P}_{j}^{(l)},(j=\overline{1, t})$; and a vector $\mathrm{M}_{\text {rez }}^{(l)}$ containing the basic probability assignments $m_{\mathrm{rez}}\left(P_{r i}^{(l)}\right)$ of the resulting subsets $P_{r i}^{(l)}$ for the category $K_{l}$.

2.4 Making a collective ranking of the analyzed objects

On the next stage, the collective ranking of the analyzed objects is formed for a given category $K_{l}$ in accordance with Stages 1.4-1.5.

As a result of this procedure, a set $\mathrm{R}_{r e z}=\left\{R K_{l} \mid l=\overline{1, s}\right\}$ will be formed, with elements corresponding to collective rankings of the analyzed objects for each category of TC. 


\section{EXPERIMENTS}

The purpose of the experiment was to demonstrate the proposed methodology for determining the TC category of analyzed construction objects (buildings and structures), and ranking of the corresponding construction objects within the given TC category according to the degree of the need of an overhaul.

The proposed methodology is implemented in a $\mathrm{C}++$ development environment Microsoft Visual Studio 2017.

As an example, that shows how proposed approach can be used in practical applications, the analysis of the technical condition of four real estate objects of the municipal non-residential fund has been done.

Based on the obtained quantitative and qualitative indicators of the serviceability of the buildings and structures under consideration $\mathrm{A}=\left\{A_{i} \mid i=\overline{1,4}\right\}$, a group of experts $\mathrm{E}=\left\{E_{j} \mid j=\overline{1, t}\right\}, t=5$, was asked to put a TC category $K_{l}, \mathrm{~K}=\left\{K_{l} \mid l=\overline{1,4}\right\}$, into compliance with each of the given alternatives $A_{i}$, and for the given TC category $K_{l}$ identify the one (s) $A_{i}^{(l)}$ that is (are) most in need of an overhaul in a given scale of relations.

For the considered example, the nine-point comparison scale was used: 1 - equal importance; 3 moderate superiority; 5 - significant superiority; 7 - clear superiority; 9 - absolute domination; the values 2, 4, 6, 8 correspond to intermediate gradations [20].

The current Ukrainian regulation standards in the field of inspection, certification, safe and reliable operation of buildings and structures determine four categories of TC: normal, satisfactory, not suitable for normal operation, emergency.

\section{RESULTS}

At the first stage of proposed methodology a group of experts $\mathrm{E}=\left\{E_{j} \mid j=\overline{1, t}\right\}, t=5$ was asked to put a TC category $K_{l}$ into compliance with each of the given alternatives $\mathrm{A}=\left\{A_{i} \mid i=\overline{1,4}\right\}$, or specify preferred groups of TC categories.

Table 1 shows the results of an expert survey: subgroups of alternatives (focal elements) identified by experts and their degree of preference.
Table 1 - Degree of preference for alternatives identified by experts

\begin{tabular}{|c|c|c|c|c|c|c|c|c|}
\hline \multirow{2}{*}{$E_{j}$} & \multirow{2}{*}{$\begin{array}{l}\text { Expert preference } \\
\text { profiles, } \gamma_{j}\end{array}$} & \multicolumn{7}{|c|}{ Alternatives, $A_{i}$} \\
\hline & & \multicolumn{2}{|c|}{$A_{1}$} & \multicolumn{2}{|c|}{$A_{2}$} & \multicolumn{2}{|c|}{$A_{3}$} & $A_{4}$ \\
\hline \multirow{2}{*}{$E_{1}$} & $Y_{k} \subseteq X_{1}^{(i)}$ & $K_{2}$ & - & $K_{2}$ & - & $K_{3}$ & - & $K_{2}$ \\
\hline & $b_{k} \subseteq B_{1}^{(i)}$ & 7 & - & 4 & - & 6 & - & 7 \\
\hline \multirow{2}{*}{$E_{2}$} & $Y_{k} \subseteq X_{2}^{(i)}$ & $K_{1}$ & - & $K_{2}$ & $K_{3}$ & $K_{3}$ & - & $K_{2}$ \\
\hline & $b_{k} \subseteq B_{2}^{(i)}$ & 6 & - & 2 & 6 & 7 & - & 6 \\
\hline \multirow{2}{*}{$E_{3}$} & $Y_{k} \subseteq X_{3}^{(i)}$ & $K_{1}$ & $K_{2}$ & $K_{2}$ & - & $K_{2}$ & $K_{3}$ & $K_{3}$ \\
\hline & $b_{k} \subseteq B_{3}^{(i)}$ & 4 & 6 & 6 & - & 3 & 5 & 9 \\
\hline \multirow{2}{*}{$E_{4}$} & $Y_{k} \subseteq X_{4}^{(i)}$ & $K_{2}$ & - & $K_{2}$ & - & $K_{3}$ & $K_{4}$ & $K_{2}$ \\
\hline & $b_{k} \subseteq B_{4}^{(i)}$ & 6 & - & 4 & - & 6 & 3 & 4 \\
\hline \multirow{2}{*}{$E_{5}$} & $Y_{k} \subseteq X_{5}^{(i)}$ & $K_{2}$ & - & $K_{3}$ & - & $K_{3}$ & - & $K_{3}$ \\
\hline & $b_{k} \subseteq B_{5}^{(i)}$ & 7 & - & 6 & - & 5 & - & 6 \\
\hline
\end{tabular}

Next, based on (2)-(3), the basic probability assignments for each of the selected subsets of the frame of discernment A have been calculated. The results obtained are shown in Table 2.

The following experts' competence coefficients values were used: $0.2,0.3,0.25,0.1,0.15$, respectively. Weight coefficients, which reflect the competence of experts in the analysis of the current problem can be determined, for example, on the basis of one of the methods proposed in [21-24].

The order of combination was established based on the obtained metric values (4), and the resulting bpa values were calculated based on the combination rule (5).

For the alternative $A_{1}$, the combination of the obtained bpas was performed in the following order:

1. Combination of bpas formed by experts $E_{1}$ and $E_{5}$, with $\min d\left(m_{\mathrm{i}}, m_{\mathrm{j}}\right)=d\left(m_{1}, m_{5}\right)=0.061$.

Combination results:

$$
\begin{gathered}
m_{15}\left(K_{2}\right)=0.794 ; \\
m_{15}(\mathrm{~K})=0.206 .
\end{gathered}
$$

Table 2 - The basic probability assignments of subgroups of alternatives identified by experts

\begin{tabular}{|c|c|c|c|c|}
\hline \multirow{2}{*}{ Experts, $E_{j}$} & \multicolumn{4}{|c|}{ Basic probability assignments, $m_{k}\left(Y_{k}\right)$} \\
\cline { 2 - 5 } & $A_{1}$ & $A_{2}$ & $A_{3}$ & $A_{4}$ \\
\hline \multirow{2}{*}{$E_{1}$} & $m_{1}\left(K_{2}\right)=0.58$ & $m_{1}\left(K_{2}\right)=0.44$ & $m_{1}\left(K_{3}\right)=0.55$ & $m_{1}\left(K_{2}\right)=0.58$ \\
\cline { 2 - 5 } & $m_{1}(\mathrm{~K})=0.42$ & $m_{1}(\mathrm{~K})=0.56$ & $m_{1}(\mathrm{~K})=0.45$ & $m_{1}(\mathrm{~K})=0.42$ \\
\hline \multirow{3}{*}{$E_{2}$} & $m_{2}\left(K_{1}\right)=0.64$ & $m_{2}\left(K_{2}\right)=0.16$ & $m_{2}\left(K_{3}\right)=0.67$ & $m_{2}\left(K_{2}\right)=0.64$ \\
\cline { 2 - 5 } & $m_{2}(\mathrm{~K})=0.36$ & $m_{2}\left(K_{3}\right)=0.47$ & $m_{2}(\mathrm{~K})=0.33$ & $m_{2}(\mathrm{~K})=0.36$ \\
\cline { 2 - 5 } & - & $m_{2}(\mathrm{~K})=0.37$ & - & $m_{3}\left(K_{3}\right)=0.7$ \\
\cline { 2 - 5 }$E_{3}$ & $m_{3}\left(K_{2}\right)=0.38$ & $m_{3}\left(K_{2}\right)=0.6$ & $m_{3}\left(K_{2}\right)=0.22$ & $m_{3}(\mathrm{~K})=0.3$ \\
\cline { 2 - 5 } & $m_{3}\left(K_{1}\right)=0.26$ & $m_{3}(\mathrm{~K})=0.4$ & $m_{3}\left(K_{3}\right)=0.37$ & - \\
\hline \multirow{3}{*}{$E_{4}$} & $m_{3}(\mathrm{~K})=0.36$ & - & $m_{4}\left(K_{3}\right)=0.26$ & $m_{4}\left(K_{2}\right)=0.29$ \\
\cline { 2 - 5 } & $m_{4}\left(K_{2}\right)=0.37$ & $m_{4}\left(K_{2}\right)=0.29$ & $m_{4}\left(K_{4}\right)=0.13$ & $m_{4}(\mathrm{~K})=0.71$ \\
\cline { 2 - 5 } & $m_{4}(\mathrm{~K})=0.63$ & $m_{4}(\mathrm{~K})=0.71$ & $m_{4}(\mathrm{~K})=0.61$ & - \\
\hline \multirow{2}{*}{$E_{5}$} & - & $m_{5}\left(K_{3}\right)=0.47$ & $m_{5}\left(K_{2}\right)=0.43$ & $m_{5}\left(K_{2}\right)=0.47$ \\
\cline { 2 - 5 } & $m_{5}\left(K_{2}\right)=0.51$ & $m_{5}(\mathrm{~K})=0.53$ & $m_{5}(\mathrm{~K})=0.57$ & $m_{5}(\mathrm{~K})=0.53$ \\
\hline
\end{tabular}

(C) Shved A. V., 2019

DOI 10.15588/1607-3274-2019-4-9 
2. Combination of bpas formed by experts $E_{3}$ and $E_{4}$, with $d\left(m_{3}, m_{4}\right)=0.228$.

Combination results:

$$
\begin{gathered}
m_{34}\left(K_{1}\right)=0.2 ; \\
m_{34}\left(K_{2}\right)=0.57 ; \\
m_{34}(\mathrm{~K})=0.23 .
\end{gathered}
$$

3. Combination of bpas $m_{15}(\cdot)$ and $m_{34}(\cdot)$, with $d\left(m_{15}, m_{34}\right)=0.213$.

Combination results:

$$
\begin{gathered}
m_{1345}\left(K_{1}\right)=0.073 ; \\
m_{1345}\left(K_{2}\right)=0.879 ; \\
m_{1345}(\mathrm{~K})=0.048 .
\end{gathered}
$$

4. Combination of bpas $m_{1345}(\cdot)$ and $m_{2}(\cdot)$.

Combination results:

$$
\begin{aligned}
& m_{12345}\left(K_{1}\right)=0.34 ; \\
& m_{12345}\left(K_{2}\right)=0.64 ; \\
& m_{12345}(\mathrm{~K})=0.02 .
\end{aligned}
$$

Thus, the following results were obtained:

$$
\begin{aligned}
& X_{\text {rez }}^{(1)}=\left\{\left\{K_{1}\right\},\left\{K_{2}\right\},\{\mathrm{K}\}\right\} ; \\
& \mathrm{M}_{\text {rez }}^{(1)}=\{0.34,0.64,0.02\} .
\end{aligned}
$$

As can be seen from the above, the maximum value of bpa was obtained for TC category $K_{2}$. Therefore, the alternative $A_{1}$ corresponds to the category $K_{2}$, (satisfactory state). Similar calculations were performed for all alternatives:

$$
\begin{gathered}
X_{\text {rez }}^{(2)}=\left\{\left\{K_{2}\right\},\left\{K_{3}\right\},\{\mathrm{K}\}\right\} ; \\
\mathrm{M}_{\text {rez }}^{(2)}=\{0.6,0.37,0.03\} ; \\
X_{\text {rez }}^{(3)}=\left\{\left\{K_{2}\right\},\left\{K_{3}\right\},\left\{K_{4}\right\},\{\mathrm{K}\}\right\} ; \\
\mathrm{M}_{\text {rez }}^{(3)}=\{0.20,0.77,0.01,0.02\} ; \\
X_{\text {rez }}^{(4)}=\left\{\left\{K_{2}\right\},\left\{K_{3}\right\},\{\mathrm{K}\}\right\} ; \\
\mathrm{M}_{\text {rez }}^{(4)}=\{0.66,0.32,0.02\} .
\end{gathered}
$$

The following conclusions can be drawn from the results of our research: objects $A_{1}, A_{2}, A_{4}$ were assigned to the category $K_{2}$; object $A_{3}$ was assigned to the category $K_{3}$.

At the second stage of proposed methodology the task of the ranking of building objects within the category $K_{2}$ was considered, for selecting the object (s) that is (are) most in need of an overhaul.

Within the specified category, the expert group was invited to evaluate a number of objects belonging to the category in question. This procedure can be carried out for ranking objects for all categories of TC.

The degree of preference of expert evidence in a ninepoint ratio scale is shown in Table 3 .
Table 3 - Degree of preference of expert evidence

\begin{tabular}{|c|c|c|c|c|}
\hline $\begin{array}{c}\text { Experts, } \\
E_{j}\end{array}$ & $\begin{array}{c}\text { Expert } \\
\text { preference } \\
\text { profiles }\end{array}$ & \multicolumn{3}{|c|}{ Expert evidence } \\
\hline \multirow{4}{*}{$E_{1}$} & $P_{i}^{(2)} \subseteq \mathrm{P}_{1}^{(2)}$ & $\left\{A_{1}\right\}$ & $\left\{A_{2}, A_{4}\right\}$ & - \\
\cline { 2 - 5 } & $\omega_{i}^{(2)} \subseteq \Omega_{1}^{(2)}$ & 7 & 3 & - \\
\hline \multirow{4}{*}{$E_{2}$} & $P_{i}^{(2)} \subseteq \mathrm{P}_{2}^{(2)}$ & $\left\{A_{1}\right\}$ & $\left\{A_{2}\right\}$ & $\left\{A_{4}\right\}$ \\
\cline { 2 - 5 } & $\omega_{i}^{(2)} \subseteq \Omega_{2}^{(2)}$ & 5 & 4 & 7 \\
\hline \multirow{4}{*}{$E_{3}$} & $P_{i}^{(2)} \subseteq \mathrm{P}_{3}^{(2)}$ & $\left\{A_{1}, A_{2}\right\}$ & $\left\{A_{4}\right\}$ & - \\
\cline { 2 - 5 } & $\omega_{i}^{(2)} \subseteq \Omega_{3}^{(2)}$ & 7 & 5 & - \\
\hline \multirow{3}{*}{$E_{4}$} & $P_{i}^{(2)} \subseteq \mathrm{P}_{4}^{(2)}$ & $\left\{A_{1}\right\}$ & $\left\{A_{4}\right\}$ & - \\
\cline { 2 - 5 } & $\omega_{i}^{(2)} \subseteq \Omega_{4}^{(2)}$ & 5 & 7 & - \\
\hline \multirow{2}{*}{$E_{5}$} & $P_{i}^{(2)} \subseteq \mathrm{P}_{5}^{(2)}$ & $\left\{A_{2}, A_{4}\right\}$ & - & - \\
\cline { 2 - 5 } & $\omega_{i}^{(2)} \subseteq \Omega_{5}^{(2)}$ & 6 & - & - \\
\hline
\end{tabular}

The basic probability assignments for each of the selected subsets of the frame of discernment were calculated based on (2)-(3):

Expert $E_{1}$ :

$$
\begin{gathered}
m_{1}\left(A_{1}\right)=0.41 ; \\
m_{1}\left(A_{2}, A_{4}\right)=0.18 ; \\
m_{1}(\mathrm{~A})=0.41
\end{gathered}
$$

Expert $E_{2}$ :

$$
\begin{aligned}
& m_{2}\left(A_{1}\right)=0.23 \\
& m_{2}\left(A_{2}\right)=0.18 \\
& m_{2}\left(A_{4}\right)=0.32 \\
& m_{2}(\mathrm{~A})=0.27
\end{aligned}
$$

Expert $E_{3}$ :

$$
\begin{gathered}
m_{3}\left(A_{1}, A_{2}\right)=0.4 ; \\
m_{3}\left(A_{4}\right)=0.28 \\
m_{3}(\mathrm{~A})=0.32
\end{gathered}
$$

Expert $E_{4}$ :

$$
\begin{gathered}
m_{4}\left(A_{1}\right)=0.19 \\
m_{4}\left(A_{4}\right)=0.27 \\
m_{4}(\mathrm{~A})=0.54
\end{gathered}
$$

Expert $E_{5}$ :

$$
\begin{gathered}
m_{5}\left(A_{2}, A_{4}\right)=0.47 \\
m_{5}(\mathrm{~A})=0.53
\end{gathered}
$$

Calculate the value of the measure (4):

$$
\begin{array}{ll}
d\left(m_{1}, m_{2}\right)=0.258 ; & d\left(m_{1}, m_{3}\right)=0.288 \\
d\left(m_{1}, m_{4}\right)=0.218 ; & d\left(m_{1}, m_{5}\right)=0.374 \\
d\left(m_{2}, m_{3}\right)=0.220 ; & d\left(m_{2}, m_{4}\right)=0.174 ; \\
d\left(m_{2}, m_{5}\right)=0.373 ; & d\left(m_{3}, m_{4}\right)=0.197 \\
d\left(m_{3}, m_{5}\right)=0.337 ; & d\left(m_{4}, m_{5}\right)=0.316
\end{array}
$$

The metric (4) reaches the smallest value for evidence of experts $E_{2}$ and $E_{4}$. Therefore, we are the first to combine evidence $m_{2}(\cdot)$ and $m_{4}(\cdot)$. 
The order of expert evidence combination:

$$
\begin{aligned}
\text { 1. } m_{24}= & m_{2} \oplus m_{4} ; d\left(m_{2}, m_{4}\right)=0.174 ; \\
\text { 2. } m_{13}= & m_{1} \oplus m_{3} ; d\left(m_{1}, m_{3}\right)=0.288 ; \\
\text { 3. } m_{1234}= & m_{13} \oplus m_{24} ; d\left(m_{13}, m_{24}\right)=0.197 ; \\
& \text { 4. } m_{12345}=m_{1234} \oplus m_{5}
\end{aligned}
$$

The combination of expert evidence was carried out on the basis of rule (5).

Resulting bpas:

$$
\begin{gathered}
m_{\mathrm{rez}}\left(A_{1}\right)=0.32 ; \\
m_{\mathrm{rez}}\left(A_{2}\right)=0.117 ; \\
m_{\mathrm{rez}}\left(A_{4}\right)=0.41 ; \\
m_{\mathrm{rez}}\left(A_{1}, A_{2}\right)=0.023 ; \\
m_{\mathrm{rez}}\left(A_{2}, A_{4}\right)=0.12 ; \\
m_{\mathrm{rez}}(A)=0.01 .
\end{gathered}
$$

Based on the obtained combined basic probability assignments, the values of belief and plausibility function have been calculated using equations (6)-(7) for all analyzed alternatives:

$$
\begin{gathered}
A_{1}:\left\{\begin{array}{l}
\operatorname{Bel}\left(\left\{A_{1}\right\}\right)=m_{12345}\left(\left\{A_{1}\right\}\right)=0.32 ; \\
\operatorname{Pl}\left(\left\{A_{1}\right\}\right)=m_{12345}\left(\left\{A_{1}\right\}\right)+ \\
+m_{12345}\left(\left\{A_{1}, A_{2}\right\}\right)+m_{12345}(\{\mathrm{~A}\})=0.353,
\end{array}\right. \\
A_{2}:\left\{\begin{array}{l}
\operatorname{Bel}\left(\left\{A_{2}\right\}\right)=m_{12345}\left(\left\{A_{2}\right\}\right)=0.117 ; \\
\operatorname{Pl}\left(\left\{A_{2}\right\}\right)=m_{12345}\left(\left\{A_{2}\right\}\right)+m_{12345}\left(\left\{A_{1}, A_{2}\right\}\right)+ \\
+m_{12345}\left(\left\{A_{2}, A_{4}\right\}\right)+m_{12345}(\{\mathrm{~A}\})=0.27,
\end{array}\right. \\
A_{4}:\left\{\begin{array}{l}
\operatorname{Bel}\left(\left\{A_{4}\right\}\right)=m_{12345}\left(\left\{A_{4}\right\}\right)=0.41 ; \\
\operatorname{Pl}\left(\left\{A_{4}\right\}\right)=m_{12345}\left(\left\{A_{4}\right\}\right)+m_{12345}\left(\left\{A_{2}, A_{4}\right\}\right)+ \\
+m_{12345}(\{\mathrm{~A}\})=0.54 .
\end{array}\right.
\end{gathered}
$$

The maximum degree of support represented by $A_{1}$ is 0.35 ; the maximum degree of support represented by $A_{2}$ is 0.27 ; the maximum degree of support represented by $A_{4}$ is 0.54 . It can be seen from the above that the obtained confidence intervals do not overlap and we can conclude that the choice $A_{4}$ has the highest values of the belief and plausibility function, without using coefficient (8).

As a result of the analysis, we obtain a ranking of alternatives of the following form: $A_{4} \succ A_{1} \succ A_{2}$.

Thus, we can conclude that among the objects considered in the framework of the category $K_{2}$, the object $A_{4}$ needs reconstruction or repair in the first place.

\section{DISCUSSION}

The methodology for determining the TC category of analyzed construction objects (buildings and structures), and ranking of the corresponding construction objects within the given TC category according to the degree of the need of an overhaul has been proposed in this paper.

The peculiarity of the proposed approach lies in the fact that, based on the obtained quantitative and qualitative characteristics of TC of the analyzed objects for each TC category, the ranking of the analyzed objects has been built. After performing this procedure, based on (C) Shved A. V., 2019

DOI 10.15588/1607-3274-2019-4-9 the expert evidence, each object of expertise can be put in line with the TC category. Thus, for each object of expertise, it is possible to establish priority TC categories, and accordingly for each category of TC to determine the objects corresponding to it.

Unlike existing approaches, the proposed methodology is focused on the analysis of group expert assessments under multi-alternativeness and allows synthesizing collective ranking taking into account specific types of uncertainty (inconsistency, incompleteness, inaccuracy and others) under the influence of which expert judgments are formed. Such benefits are achieved by using the expert evidence combination mechanism, for the aggregation of individual expert assessments based on the mathematical apparatus of evidence theory, and proportional conflict redistribution rules.

The mathematical apparatus of evidence theory allows modeling the uncertainty in expert judgments through the presentation of inaccuracies in expert assessments (an expert can refuse to evaluate a specific object, evaluate a group of priority objects at once). The absence of limitations on the form of expert data (interval or crisp expert estimates) enables the expert to express his opinion on the subject under consideration as accurately as possible, which in turn would allow increasing the efficiency of his work.

The above numerical calculations show the effectiveness of the proposed approach under conditions of incomplete (an expert may refuse to evaluate an object) and conflicting (inconsistent) expert information.

The proposed approach can be used as an addition to existing methods for evaluation of the TC of buildings and structures, and selection of priority objects for further reconstruction and overhaul.

\section{CONCLUSIONS}

The methodology for the synthesis of group decisions to determine the TC category of military-civilian construction objects, including buildings and structures, and selection of the construction objects for the reconstruction, overhaul under uncertainty of the expert data, has been proposed in this paper. The application of this technique will improve the efficiency of trouble-free operation of military-civilian objects.

The scientific novelty of obtained results lies in the fact that the method for aggregating the expert judgments of TC categories of building constructions and structures under group decision making, based on the mathematical apparatus of evidence theory, has been improved. By contrast to existing group expert's evaluation methods, which are based on the mechanism of pairwise comparison, the proposed technique allows to remove restrictions on the number of analyzed objects of examination, and the necessary condition for the consistency of expert's assessments. The obtained results are adapted to the features of the analysis of group expert assessments formed under large expert groups, complex types of uncertainty, multi-alternatives, conflicting, and contradicting expert judgments. 
The practical significance of obtained results indicates the possibility of applying a qualitatively new approach to solving the problem of the TC evaluation of military-civilian objects under uncertainty and inaccuracy of the expert data. The proposed approach constitutes the theoretical basis for the construction of an automated decision support system for implementing projects of the TC assessment of military-civilian objects.

Prospects for further research are to develop scientifically based approaches to obtaining objective and reliable expert information that would improve the quality and reliability of the received expert evidence; to state methods of formation of the composition of an expert group in accordance with expert level of competence.

\section{ACKNOWLEDGEMENTS}

The work is supported by the state budget scientific research project of Petro Mohyla Black Sea National University "Development of information and communication decision support technologies for strategic decision-making with multiple criteria and uncertainty for military-civilian use" (state registration number 0117U007144).

\section{REFERENCES}

1. Kwan A., Ng P. L. Building diagnostic techniques and building diagnosis: the way forward, Engineering Asset Management - Systems, Professional Practices and Certification, 2015, Vol. 19, pp. 849-862. DOI: 10.1007/978-3-319-09507-3 74

2. Vilhena A., Pedro J. B., Brito J. Comparison of methods used in European countries to assess buildings' condition, Proceedings of the 12th International Conference on Durability of Building Materials and Components, 2011, Porto, pp. 1-7. DOI: 10.13140/RG.2.1.3460.7124

3. Mitra G., Jain K. K., Bhattacharjee B. Condition assessment of corrosion distressed reinforced concrete buildings using fuzzy logic, Journal of Performance of Constructed Facilities, 2010, Vol. 24, No. 6, pp. 652-569. DOI: $10.1061 /(A S C E) C F .1943-5509.0000137$

4. Holicky M., Navarova V., Gottfried R., Kronika M., Markova J., Sykora M., Jung K. Basics for assessment of existing structures. Prague, Klokner Institute, Czech Technical University, 2013, 109 p.

5. Wahida R., Milton G., Hamadan N. et al. Building condition assessment imperative and process, Procedia - Social and Behavioral Sciences, 2012, Vol. 65, pp. 775-780. DOI: 10.1016/j.sbspro.2012.11.198

6. Hamdia K. M., Arafa M., Alqedra M. Structural damage assessment criteria for reinforced concrete buildings by using a Fuzzy Analytic Hierarchy Process, Underground Space, 2018, Vol. 3, No. 3, pp. 243-249. DOI: 10.1016/j.undsp.2018.04.002

7. Gao Z., Li J. Fuzzy Analytic Hierarchy Process evaluation method in assessing corrosion damage of reinforced concrete bridges, Civil Engineering Journal, 2018, Vol. 4, No. 4, pp. 843-856. DOI: 10.28991/cej-0309138

8. Rashidi M., Gibson P. A methodology for bridge condition evaluation, Journal of Civil Engineering and Architecture, 2012, Vol. 6, No. 9, pp. 1149-1157. DOI: 10.17265/19347359/2012.09.007

9. Ter Berg C. J. A., Leontaris G., Van den Boomen M. et al. Expert judgments based maintenance decision support method for structures with a long service-life, Structure and Infrastructure Engineering, 2019, Vol. 15, No. 4, pp. 492503. DOI: $10.1080 / 15732479.2018 .1558270$

10. Grigorovskiy P., Terentyev O., Mikautadze R. Development of the technique of expert assessment in the diagnosis of the technical condition of buildings, Technology Audit and Production Reserves, 2017, No. 2, pp. 10-15. DOI: $10.15587 / 2312-8372.2018 .128548$

11. Abbott G. R., Mc Duling J. J., Parsons S. at el. Building condition assessment: a performance evaluation tool towards sustainable asset management, Proceedings of the 2007 CIB World building Congress: Construction for Development, Cape Town, 2007, pp. 649-662.

12. Jo H. W., Jung I. S., Lee C. S. Fuzzy based condition assessment model prototype of middle and small-size buildings, Proceedings of the 28th International Symposium on Automation and Robotics in Construction (ISARC), Seoul, 2011, pp. 1330-1331. DOI: $10.22260 /$ ISARC2011/0246

13. Terentyev O., Malyna B. Expert information system for decision support for the problem of diagnostics of technical condition of buildings, International Journal of Science and Research, 2015, Vol. 4, No. 10, pp. 652-654.

14. Chen Z., Clements-Croome D., Bakker H. H. C. at el. A remote expert system for building diagnosis, Proceedings of the 8th International Conference and Exhibition on Healthy Buildings: Creating a Healthy Indoor Environment for People, Lisboa, 2006, pp. 99-104.

15. Dempster A. P. Upper and lower probabilities induced by a multi-valued mapping, Annals of Mathematical Statistics, 1967, Vol. 38, pp. 325-339.

16. Shafer G. A mathematical theory of evidence. Princeton, Princeton University Press, 1976, 297 p.

17. Beynon M. J., Curry B., Morgan P. The Dempster-Shafer theory of evidence: an alternative approach to multicriteria decision modeling, Omega, 2000, Vol. 28, No. 1, pp. 37-50.

18. Jousselme A. L., Grenier D., Boss'e E. A new distance between two bodies of evidence, Information Fusion, 2001, Vol. 2, pp. 91-101.

19. Smarandache F. Advances and applications of DSmT for information fusion. Vol. 1. Rehoboth, American Research Press, 2004, 760 p.

20. Saaty T. The Analytic Hierarchy Process: panning, priority setting, resource allocation. Front cover. New York, McGraw Hill, 1980, 287 p.

21. Velychko O. M., Gordiyenko T. B., Kolomiets L. V. Methodologies of expert's competence evaluation and group expert evaluation, Metallurgical and Mining Industry, 2015, Vol. 7, No. 2, pp. 262-271

22. Velychko O. M., Gordiyenko T. B., Kolomiets L. V. Comparative analysis of the assessment results of the competence of technical experts by different methods, Eastern-European Journal of Enterprise Technologies, 2017, Vol. 4, No. 3 (88), pp. 4-10. DOI: 10.15587/17294061.2017.106825

23. Borissova D. A group decision making model considering experts competency: An application in personnel selection, Comptes Rendus de l'Academie Bulgare des Sciences: Sciences Mathematiques et Naturelles, 2018, Vol. 71, No. 11, pp. 1520-1527. DOI: 10.7546/CRABS.2018.11.11

24. Becker J., Becker A., Salabun W. Construction and use of the ANP decision model taking into account the experts' competence, Procedia Computer Science, 2017, Vol. 112, pp. 2269-2279. DOI: 10.1016/j.procs.2017.08.145 


\section{СИНТЕЗ ГРУПОВИХ РІШЕНЬ В ЗАДАЧІ АНАЛІЗУ ТЕХНІЧНОГО СТАНУ БУДІВЕЛЬНИХ ОБ'ЄКТІВ ВІЙСЬКОВО-ЦИВІЛЬНОГО ПРИЗНАЧЕННЯ}

Швед А. В. - канд. техн. наук, доцент кафедри інженерії програмного забезпечення Чорноморського національного університету імені Петра Могили, Миколаїв, Україна.

Актуальність. Досить часто при проведенні процедур діагностики і моніторингу технічного стану будівель і споруд залучаються експерти-фахівці, при цьому виникають ситуації, коли дані, отримані експертним шляхом формуються в умовах специфічних видів невизначеності, та їх можливих комбінацій. Це обумовлює необхідність розробки нових підходів спрямованих на вирішення завдань структуризації та аналітичної обробки неточних, невизначених, нечітких експертних знань.

Метод. Запропонована в роботі методика спрямована на визначення категорії технічного стану та ранжування відповідних будівельних об'єктів в рамках заданої категорії технічного стану за ступенем їх небезпеки (очікуваного збитку при настанні аварійної ситуації). В основі запропонованої методики лежать методи експертного оцінювання та методів теорії свідоцтв, які дозволяють обробляти експертні судження сформовані в умовах невизначеності, неповноти, неточності. 3 метою підвищення якості результатів комбінування запропоновано використовувати правила перерозподілу конфліктів та визначати порядок комбінування експертних свідоцтв на основі метрик теорії свідоцтв.

Результати. В роботі запропоновано методику синтезу групових рішень оцінки технічного стану об'єктів цивільного, промислового та військово-технічного призначення, та визначення таких об'єктів, які першочергово потребують ремонтнобудівельних робіт (капітального ремонту, реконструкції тощо) в умовах складних форм невизначеності та багатоальтернативності. Застосування запропонованої методики дозволить раціонально розподіляти наявні ресурси при плануванні попереджувальних заходів і проведення ремонтних робіт з метою запобігання можливих негативних наслідків (обмеження працездатності, аварійного стану) та підвищення ефективності їх безаварійної експлуатації.

Висновки. Запропонована методика становить теоретичне підгрунтя для проектування систем підтримки прийняття рішення задач моніторингу технічного стану об'єктів житлової та нежитлової нерухомості (будівель, споруд) різного призначення.

КЛЮЧОВІ СЛОВА: теория свідоцтв, категорія технічного стану, ранжування, експертні оцінки, невизначеність.

УДК 519.816:624

\section{СИНТЕЗ ГРУППОВЫХ РЕШЕНИЙ В ЗАДАЧЕ АНАЛИЗА ТЕХНИЧЕСКОГО СОСТОЯНИЯ ОБЪЕКТОВ} ВОЕННО-ГРАЖДАНСКОГО НАЗНАЧЕНИЯ

Швед А. В. - канд. техн. наук, доцент кафедры инженерии программного обеспечения Черноморского национального университета имени Петра Могилы, Николаев, Украина.

\section{АННОТАЦИЯ}

Актуальность. Достаточно часто при проведении процедур диагностики и мониторинга технического состояния зданий и сооружений привлекаются эксперты-специалисты, при этом возникают ситуации, когда данные, полученные экспертным путем, формируются в условиях специфических видов неопределенности, и их возможных комбинаций. Это в свою очередь обуславливает необходимость разработки новых подходов направленных на решение задач структурирования и аналитической обработки неточных, неопределенных, нечетких экспертных знаний.

Метод. В работе предложена методика выбора категории технического состояния и ранжирования соответствующих строительных объектов в рамках заданной категории технического состояния по степени их опасности (ожидаемого ущерба при возникновении аварийной ситуации). В основе предложенной методики лежат методы экспертного оценивания и теории свидетельств, которые позволяет корректно оперировать с данными, сформированными в условиях неопределенности, неполноты, неточности. С целью повышения качества результатов комбинирования предложено использовать правила перераспределения конфликтов и определять оптимальный порядок комбинирования на основе метрик теории свидетельств.

Результаты. В работе предложена методика синтеза групповых решений оценки технического состояния объектов гражданского, промышленного и военно-технического назначения, и определение объектов, которые в первую очередь нуждаются в проведении ремонтных работ (капитальный ремонт, реконструкция и т.д.) в условия сложных форм неопределенности и многоальтернативности. Применение предложенной методики позволит рационально распределять имеющиеся ресурсы при планировании предупредительных мероприятий и проведения ремонтных работ с целью повышения эффективности их безаварийной эксплуатации.

Выводы. Предложенная методика составляет теоретическое основание для проектирования систем поддержки принятия решения задач мониторинга технического состояния объектов жилой и / или нежилой недвижимости (зданий, сооружений) разного назначения.

КЛЮЧЕВЫЕ СЛОВА: теория свидетельств, категория технического состояния, ранжирование, экспертные оценки, неопределенность.

\section{ЛІТЕРАТУРА / ЛИТЕРАТУРА}

1. Kwan A. Building diagnostic techniques and building diagnosis: the way forward / A. Kwan, P. L. Ng // Engineering Asset Management - Systems, Professional Practices and Certification. - Springer, 2015. - Vol. 19. P. 849-862. DOI: 10.1007/978-3-319-09507-3_74

(C) Shved A. V., 2019

DOI 10.15588/1607-3274-2019-4-9
2. Vilhena A. Comparison of methods used in European countries to assess buildings' condition / A. Vilhena, J. B. Pedro, J. de Brito // Durability of Building Materials and Components: 12th International Conference, Porto, 1215 April 2011: proceedings. - Porto: FEUP, DL 2011. P. 1-7. DOI: 10.13140/RG.2.1.3460.7124

3. Mitra G. Condition assessment of corrosion distressed reinforced concrete buildings using fuzzy logic / G. Mitra, 
K. K. Jain, B. Bhattacharjee // Journal of Performance of Constructed Facilities. - 2010. - Vol. 24, № 6. - P. 652569. DOI: 10.1061/(ASCE)CF.1943-5509.0000137

4. Basics for assessment of existing structures / [M. Holicky, V. Navarova, R. Gottfried et al.]. - Prague: Klokner Institute, Czech Technical University, 2013. - 109 p.

5. Building condition assessment imperative and process [R. Wahida, G. Milton, N. Hamadan et al.] // Procedia Social and Behavioral Sciences. - 2012. - Vol. 65. - P. 775780. DOI: 10.1016/j.sbspro.2012.11.198

6. Hamdia K. M. Structural damage assessment criteria for reinforced concrete buildings by using a Fuzzy Analytic Hierarchy process / K. M. Hamdia, M. Arafa, M. Alqedra // Underground Space. - 2018. - Vol. 3, № 3. - P. 243-249. DOI: 10.1016/j.undsp.2018.04.002

7. Gao Z. Fuzzy Analytic Hierarchy Process evaluation method in assessing corrosion damage of reinforced concrete bridges / Z. Gao, J. Li // Civil Engineering Journal. - 2018. - Vol. 4, № 4. - P. 843-856. DOI: 10.28991/cej-0309138

8. Rashidi M. A methodology for bridge condition evaluation / M. Rashidi, P. Gibson // Journal of Civil Engineering and Architecture. - 2012. - Vol. 6, № 9. - P. 1149-1157. DOI: $10.17265 / 1934-7359 / 2012.09 .007$

9. Ter Berg C. J. A. Expert judgement based maintenance decision support method for structures with a long servicelife / [C. J. A. Ter Berg, G. Leontaris, M. van den Boomen et al.] // Structure and Infrastructure Engineering. - 2019. Vol. 15, № 4. - P. 492-503 DOI: $10.1080 / 15732479.2018 .1558270$

10. Grigorovskiy P. Development of the technique of expert assessment in the diagnosis of the technical condition of buildings / P. Grigorovskiy, O. Terentyev, R. Mikautadze // Technology Audit and Production Reserves. - 2017. № 2. - P. 10-15. DOI: 10.15587/2312-8372.2018.128548

11. Building condition assessment: a performance evaluation tool towards sustainable asset management / [G. R. Abbott, J. J. Mc Duling, S. Parsons at el.] // Construction for Development: 2007 CIB World building Congress, Cape Town, 14-17 May 2007: proceedings. - Cape Town: International Council for Research and Innovation in Building and Construction, 2007. - P. 649-662.

12. Jo H. W. Fuzzy based condition assessment model prototype of middle and small-size buildings / H. W. Jo, I. S. Jung, C. S. Lee // International Symposium on Automation and Robotics in Construction (ISARC): 28th International Symposium, Seoul, 29 June - 2 July 2011 : proceedings. Seoul : International Association for Automation and Robotics in Construction, 2011. - P. 1330-1331. DOI: $10.22260 /$ ISARC2011/0246
13. Terentyev O. Expert information system for decision support for the problem of diagnostics of technical condition of buildings / O. Terentyev, B. Malyna // International Journal of Science and Research. - 2015. - Vol. 4, № 10. P. 652-654.

14. A remote expert system for building diagnosis / [Z. Chen, D. Clements-Croome, H. H. C. Bakker at el.] // Healthy Buildings: Creating a Healthy Indoor Environment for People: 8th International Conference and Exhibition, Lisboa, 4-8 June 2006: proceedings. - New York : Curran Associates, 2013. - Vol. 1. - P. 99-104.

15. Dempster A. P. Upper and lower probabilities induced by a multi-valued mapping / A. P. Dempster // Annals of Mathematical Statistics. - 1967. - Vol. 38. - P. 325-339.

16. Shafer G. A mathematical theory of evidence / G. Shafer. Princeton: Princeton University Press, 1976. -297 p.

17. Beynon M. J. The Dempster-Shafer theory of evidence: an alternative approach to multicriteria decision modeling / M. J. Beynon, B. Curry, P. Morgan // Omega. - 2000. Vol. 28, № 1. - P. 37-50.

18. Jousselme A. L. A new distance between two bodies of evidence / A. L. Jousselme, D. Grenier, E. Boss'e // Information Fusion. - 2001. - Vol. 2. - P. 91-101.

19. Smarandache F. Advances and applications of DSmT for information fusion / F. Smarandache, J. Dezert. - Vol. 1. Rehoboth : American Research Press, 2004. - 760 p.

20. Saaty T. The Analytic Hierarchy Process: panning, priority setting, resource allocation. Front cover / T. Saaty. - New York : McGraw Hill, 1980. - 287 p.

21. Velychko O. M. Methodologies of expert's competence evaluation and group expert evaluation / O. M. Velychko, T. B.Gordiyenko, L. V. Kolomiets // Metallurgical and Mining Industry. - 2015. - Vol. 7, № 2. - P. 262-271.

22. Velychko O. M. Comparative analysis of the assessment results of the competence of technical experts by different methods / O. M. Velychko, T. B. Gordiyenko, L. V. Kolomiets // Eastern-European Journal of Enterprise Technologies. - 2017. - Vol. 4, № 3 (88). - P. 4-10. DOI: $10.15587 / 1729-4061.2017 .106825$

23. Borissova D. A group decision making model considering experts competency: An application in personnel selection. / D. Borissova // Comptes Rendus de l'Academie Bulgare des Sciences: Sciences Mathematiques et Naturelles. - 2018. Vol. 71, № 11. - P. 1520-1527. DOI: 10.7546/CRABS.2018.11.11

24. Becker J. Construction and use of the ANP decision model taking into account the experts' competence / J. Becker, A. Becker, W. Salabun // Procedia Computer Science. 2017. - Vol. 112. - P. 2269-2279. DOI: $10.1016 /$ j.procs.2017.08.145 